\title{
IMPLEMENTASI KEBIJAKAN EKONOMI TERHADAP DESTINASI WISATA KOTA DALAM MENINGKATKAN PEMBERDAYAAN MASYARAKAT PERKOTAAN
}

\author{
Lilis Yuaningsih \\ Sekolah Tinggi Ilmu Administrasi Bandung, Jawa Barat, Indonesia \\ Lilisyuaningsih@stiabandung.ac.id
}

\begin{abstract}
The city's tourist destination is a considerable economic potential contributing to the development of the area. Tourism policy is expected to improve the local opinion, while providing economic impact to the welfare of the community. Tourist destination through Community Empowerment Program is no other to improve the economic growth of the real sector and small business as well as regional development. The methods used in the study are qualitative deskriftif, data collection with interview techniques, and study of documents then analyzed. The results of the study, that the city's tourist destination policy has given significant value to the community economy, empowerment, small business and the realization of smatcity branding and contributing to the original revenue of the city of Bandung.
\end{abstract}

Keywords: policies, travel destinations, and community empowerment

\begin{abstract}
Abstrak - Destinasi wisata kota merupakan potensi ekonomi yang cukup besar berkontribusi dalam pembangunan daerah. Dengan kebijakan kepariwisataan diharapkan dapat meningkatkan pendapat asli daerah, sekaligus memberikan dampak ekonomi bagi kesejahteraan masyarakat. Destinasi wisata melalui program pemberdayaan masyarakat tiada lain untuk meningkatkan pertumbuhan ekonomi sektor riil dan usaha kecil menengah serta pembangunan daerah. Metode yang digunakan dalam penelitian adalah deskriftif kualitatif, pengumpulan data dengan teknik wawancara, dan kajian dokumen kemudian dianalisis. Hasil penelitian, bahwa kebijakan destinasi wisata kota telah memberikan nilai signifikan terhadap ekonomi masyarakat, pemberdayaan, usaha kecil menangah dan terwujudnya smatcity branding serta berkontribusi pada pendapatan asli daerah Kota Bandung.
\end{abstract}

Kata kunci: Kebijakan, Destinasi Wisata, dan Pemberdayaan Masyarakat

\section{PENDAHULUAN}

Paris Van Java demikian favorit julukan Kota Bandung sebagai salah satu destinasi pariwisata unggulan di Jawa Barat. Percepatan destinasi pariwisata yang didukung oleh kebijakan pemerintah daerah menjadikan Kota Bandung sebagai pusat jasa, studi, dan seni budaya, serta lahirnya produk pariwisata Meeting, Incentive, Conference, Exhibition (MICE) berbasis edukasi (knowledgebased-tourism). Produk tersebut, mampu mendongkrak ekonomi masyarakat lokal dan berkontribusi signifikan terhadap pendapat asli daerah (PAD). Melalui MICE edukasi sejak tahun 2011 Kota Bandung menjadi icon Kawasan Pengembangan Pariwisata Nasional (KPPN) dan Kawasan
Strategis Pariwisata Nasional (KSPN) di Provinsi Jawa Barat.

Destinasi wisata kota merupakan bagian penting dari sumber ekonomi daerah dan masyarakat. Kawasan tujuan wisata kota yang terintegrasi dengan objek wisata lainnya di seputar Kota Bandung, telah memberikan opini positif terhadap wisatawan domestik mau-pun mancanegara, maka dengan potensi tersebut, dapat dijadikan modal destinasi kota guna meningkatkan kunjungan wisman mancanegara. Destinasi wisata kota telah menjadi industri bagi pemerintah daerah Kota Bandung, dan memberikan multiplier effect terhadap ekonomi yang berdampak langsung terhadap peningkatan pemberdayaan ekonomi masyarakat lokal. Destinasi wisata kota terbukti menjadi roda penggerak 
aktivitas ekonomi masyarakat lokal dalam suatu kawasan dan memberikan nilai ekonomi bagi kesejahteraan masyarakat. Seperti halnya kesuksesan Provinsi Bali dan Daerah Istimewa Yogyakarta.

Terdorong hal itu, Kota Bandung oleh British Council dijuluki sebuah kota kreatif di Asia Pasifik dengan pertumbuhan ekonomi yang cukup pesat. Dengan modal destinasi ini, maka rekonstruksi destinasi wisata kota di Kota Bandung sangat mungkin dikembangkan oleh pemerintah daerah dikemudian hari. Namun dalam beberapa tahun terakhir ini wisman mancanegara mengalami fluktuatif sehingga perlu dicari solusi dan kebijakan destinasi wisata kota agar ekonomi di sektor ini kembali menggeliat.

Bila dilihat destinasi wisata kota pemerintah daerah menyuguhkan pesona natural seni dan budaya masyarakat Bandung yang unik dengan daya tarik yang luar biasa agar wisman mancanegara terpesona sehingga cukup lama untuk tinggal di Kota Bandung. Wisata heritage salah satu destinasi unggulan dan peluang daya tarik yang dikemas secara edukatif sehingga para wisman memahami, mengetahui, mengalami, dan menghargai karakter heritage. Tujuannya, agar setiap wisman paham arti dari suatu budaya bangsa tidak hanya sekadar mendeskripsikan dari realitas yang ada.

Tabel 1. Kunjungan Wisman ke Kota Bandung

\begin{tabular}{|c|c|c|c|}
\hline \multirow{2}{*}{ Tahun } & \multicolumn{2}{|c|}{ Wisata } & \multirow{2}{*}{ Jumlah } \\
\cline { 2 - 3 } & Mancanegara & Domestik & \\
\hline 2011 & 225.585 & 6.487 .239 & 6.712 .824 \\
\hline 2012 & 176.855 & 5.080 .584 & 5257.439 \\
\hline 2013 & 176.432 & 5.388 .292 & 5.564 .724 \\
\hline 2014 & 180.143 & 5.627 .421 & 5.807 .564 \\
\hline 2015 & 183.932 & 5.877 .162 & 6.061 .094 \\
\hline 2016 & 173.036 & 4.827 .589 & 5.000 .625 \\
\hline
\end{tabular}

Sumber;Disbudpar Kota Bandung

Pada sisi kuliner, adalah satu aktivitas makanan masyarakat lokal khas Sunda, dengan berbagai olahan yang penyajiannya tradisional, unik, dan menyantapnya merupakan bagian menarik bagi setiap wisman. Wisata edukatif identik dengan pendidikan tematik, budaya dan lingkungan bagi pelajar dan mahasiswa sebagai bahan materi pendidikan di luar kelas. Karyawisata ini sangat bermanfaat dan terintegrasi dengan kebudayaan lokal serta lingkungan alam sebagai sumber belajar. Artinya mampu merangsang kreativitas siswa, informasi lebih luas, aktual, konstruktif, dan komprehensif, agar siswa dapat mencari serta dapat mengolah sendiri informasinya. Sebab itu, Kota Bandung sebagai objek daya tarik wisata modern banyak yang dapat ditawarkan di saat kondisi kunjungan wisman ke Kota Bandung, mengalami fluktuatif.

Berdasarkan data Disbudpar Kota Bandung, destinasi wisata kota memiliki banyak objek yang dapat dikunjungi lengkap dengan semua fasilitasnya. Hal ini guna memberikan banyak alternatif kepada wisman. Karena daya tarik wisata Kota Bandung sangat variatif dan menarik. Selain letak geografis dan lingkungan natural juga didukung oleh infrastruktur yang representatif dari kebijakan pemerintah daerah, agar terbangun iklim kondusif, mudah aksebilitas, transportasi, 
komunikasi, hotel, dan penginapan serta restoran dengan kenyamanan suasana sosiokulturan Tatar Sundanis.

Dalam kebijakan dan regulasi kepariwisataan pemerintah daerah Kota Bandung dengan mengedepankan asas norma-norma religius dan budaya masyarakat lokal, maka pengembangan destinasi wisata kota yang kreatif, someah, dan berwawasan lingkungan, diharapkan dapat menarik investasi guna mendukung pertumbuhan ekonomi masyarakat perkotaan sehingga memberdayakan masyarakat secara financial dapat tergerak pesat.

Melalui implementasi kebijakan ekonomi destinasi wisata kota di Kota Bandung, maka kualitas layanan publik semakin baik dan kondusif. Dengan demikian, seiring masuknya investasi ke Kota Bandung, maka arah dan tujuan pembangunan daerah yang berorientasi destinasi wisata kota dapat berjalan dinamis dan kondusif serta perekonomian masyarakat perkotaan semakin tumbuh.

\section{Identifikasi Masalah}

Bagaimanakah Implementasi Kebijakan Ekonomi Terhadap Destinasi Wisata Kota Dalam Meningkatkan Pemberdayaan Masyarakat Perkotaan?

\section{Tujuan Penelitian}

Untuk mengetahui bagaimana implementasi kebijakan ekonomi terhadap destinasi wisata kota dalam Meningkatkan Pemberdayaan Masyarakat perkotaan di Kota Bandung.

\section{Penjelasan singkat}

Dalam mewujudkan kebijakan ekonomi destinasi wisata kota di Kota Bandung, berdasar kepada UndangUndang Kepariwisataan Nomor 10 Tahun 2009 tentang kepariwisataan, PP Nomor 50 Tahun 2011 tentang Ripparnas, Perda Nomor 7 Tahun
2012 Tentang Penyelenggaraan

Kepariwisataan Kota Bandung, Perda Nomor 10 Tahun 2004 Tentang Penyelenggaraan Usaha Kepariwisataan, dan Perda Nomor 11 Tahun 2004 tentang Retribusi Pembinaan dan Promosi Penyelenggaraan Usaha Kepariwisataan, yang mengatur kegiatan wisata, fasilitas, dan pelayanan yang disediakan masyarakat, stakeholder, pemerintah pusat, dan pemerintah daerah. Artinya, pengembangan destinasi wisata kota tidak dapat berjalan sendiri-sendiri, namun membutuhkan kolaborasi antara pemerintah daerah dan masyarakat lokal.

Kebijakan dapat dipahami seperti pernyataan Grindle, bahwa pelaksanaan kebijakan merupakan proses tindakan administratif yang dapat diteliti pada level program tertentu. Artinya, proses pelaksanaan dapat dimulai ketika tujuan dan saran telah ditetapkan, program kegiatan telah tersusun yang didukung oleh anggaran yang siap digunakan untuk mencapai sasaran atau tujuan. Menurut Tahir, implementasi kebijakan salah satu aktivitas dalam proses kebijakan publik. Namun sering bertentangan dengan apa yang diharapkan, bahkan produk kebijakan menjadi hambatan bagi si pembuat kebijakan itu sendiri. Menurut Dunn, kebijakan publik adalah pola ketergantungan yang kompleks dari pilihan-pilihan kolektif yang berkorelasi, dan termasuk keputusan tidak bertindak, yang di buat lembaga pemerintah. Edgell, mengatakan, kebijakan destinasi wisata kota merupakan kerangka etis yang terfokus pada isu-isu destinasi yang akan dihadapi dan mempertemukan secara efektif antara keinginan dan kebutuhan masyarakat dan pemerintah dengan rencana, pembangunan, produk, 
pelayanan, marketing, dan tujuan serta sasaran. Kebijakan destinasi wisata kota mencakup keterkaitan antara kehendak, tindakan, dan hasil. Pada kehendak, kebijakan destinasi harus terefleksikan sikap pemerintah. Pada tindakan kebijakan yang terefleksikan itu harus menjadi perilaku pemerintah daerah dan pada level hasil yang akan dilakukan oleh pemerintah.

Sesuai dengan RIPP Kota Bandung, bahwa kegiatan wisata kota yang dikembangkan berdasar pada wisata belanja (shopping), hiburan, dan MICE.

Tabel 2. Kegiatan Wisata Kota Bandung

Kegiatan Utama

a. Sightseeing berupa city sightb.

b. Daya tarik wisata khusus: arsitektur gedung/bangunan dan monumen.

c. $M I C E$

Sumber : Disbudpar Kota Bandung

Kebijakan ekonomi destinasi wisata adalah landasan awal dalam setiap program pariwisata pemerintah daerah yang berkaitan dengan kepariwisataan. Dalam konteks ini, kebijakan ekonomi destinasi wisata kota tentunya sangat dinamis karena beriringan dengan kondisi sebuah kawasan yang dijadikan objek wisata.

Goeldner dan Ritchie mendefinisikan kebijakan pariwisata sebagai regulasi, pedoman, arah, sasaran pembangunan, promosi dan strategi destinasi yang dapat memberikan kerangka kerja dalam pengambilan keputusan individu maupun kolektif sehingga dapat mempengaruhi pengembangan pariwisata dalam jangka panjang. Sebab itu, kebijakan destinasi wisata kota harus dijamin oleh negara dan pemerintah daerah agar memberikan manfaat yang sebesar-besarnya dari kontribusi sosial dan ekonomi yang diberikan oleh dampak pariwisata bagi kesejahteraan masyarakat perkotaan.

Dalam konteks pemberdayaan masyarakat, menurut Bachrach dan Botwinick, dibutuhkan peran aktif masyarakat secara luas. Artinya dalam setiap destinasi wisata kota maka pemberdayaan masyarakat sangat

\section{Kegiatan Penunjang}

a. Hiburan

b. Kehidupan malam dan bioskop

c. Berbelanja penting untuk di libatkan, dan diberdayakan yang dirumuskan secara tersendiri dalam sebuah rencana pembangunan destinasi wisata kota baik secara individu maupun kelompok. Sedangkan Pendit mengatakan, bahwa dalam pemberdayaan masyarakat pariwisata dalam konteks pembangunan destinasi yang multidimensional baik langsung maupun tidak langsung, harus berorientasi pada pemberdayaan masyarakat sebagai anggotanya.

\section{METODE PENELITIAN}

Penelitian ini menggunakan pendekatan kualitatif deskriptif guna menjelaskan secara detail hasil analisis guna memperoleh gambaran mengenai perkembangan destinasi wisata kota dengan dukungan pemberdayaan masyarakat lokal. Fakta empiris menjadi perhatian penelitian untuk dianalisis secara mendalam. Data diperoleh dari dua sumber, yakni; data primer, diambil langsung dari sumbernya di lapangan, seperti datadata parsial dari Disbudpar Kota Bandung, wawancara, dan informasi pendukung dari lapangan meliputi masyarakat pelaku pariwisata, stakeholder, dan para usaha kecil dan menengah yang terdampak destinasi 
wisata kota di Kota Bandung. Data sekunder, diperoleh tidak langsung dari sumbernya, berupa dokumen-dokumen, laporan-laporan, artikel, media masa, jurnal penelitian pariwisata, dan datadata yang relevan untuk mendukung penelitian ini. Data sekunder juga diperoleh dari dokumen Disbudpar dan BPS Kota Bandung.

\section{HASIL DAN PEMBAHASAN}

\section{Kebijakan Ekonomi Destinasi Wisata Kota di Kota Bandung}

Kebijakan ekonomi terhadap destinasi wisata kota pemerintah daerah Kota Bandung, merupakan gambaran dinamisasi berfungsinya sistem ekonomi masyarakat perkotaan yang di dalamnya melibatkan berbagai unsur; seperti masyarakat pelaku wisata kota, investor sektor objek dan jasa wisata, wisman domestik dan mancanegara sebagai konsumen dan pengguna jasa wisata, dan pemerintah daerah sebagai penentu kebijakan dan penyedia sarana dan prasarana pendukung pasar destinasi wisata kota yang berkelanjutan. Daya tarik "Kota Kembang" sangat didominasi atau dipengaruhi oleh kondusivitas lingkungan dan didukung oleh faktor alam agraris natural. Objek destinasi wisata kota sebenarnya telah disediakan oleh masyarakat wisata dan para investor dengan kapasitas besar.

Hasil penelitian diperoleh bahwa setiap wisman yang datang berkunjung ke Kota Bandung berasal dari seluruh Indonesia dan mancanegara. Disbudpar salah satu dinas yang berperan aktif destinasi, memiliki peran strategis dalam mengembangkan wisata dan budaya lokal, serta berupaya mewujudkan sebagai kota wisata yang bertumpu pada jasa, studi, dan seni budaya dengan optimalisasi keunggulan seni budaya lokal. Masyarakat memiliki peran sentral dalam memberikan pelayanan jasa secara maksimal demi mewujudkan pariwisata lokal berbasis masyarakat (community based tourism).

Beberapa tahun terakhir ini, pemerintah daerah Kota Bandung telah melakukan berbagai perubahan infrastruktur kota dan promosi pariwisata guna menunjang destinasi wisata kota, sehingga mengingatkan masyarakat dunia bahwa Kota Bandung layak dikunjungi sebagai kota historikal dunia. Arah kebijakan ekonomi destinasi wisata kota pemerintah daerah Kota Bandung, selain mencanangkan visi, "Bandung sebagai Kota Tujuan Wisata dan Kota Idaman", yang dikemas menjadi dua belas tujuan, dengan model kolaboratif (top down dan bottom up) yang mengedepankan partisipasi publik secara utuh yang melibatkan berbagai stakeholder wisata. Sedangkan program-program pengembangan destinasi wisata kota mencakup produk wisata, lingkungan hidup, kualitas SDM, marketing, pelestarian seni dan budaya, dan pemanfaatan ilmu pengetahuan dan teknologi, serta penunjang program masyarakat lokal.

Pada sisi lain, pemerintah daerah dengan kebijakannya senantiasa melibatkan banyak pihak, khususnya stakeholder. Terutama pada sektor informal dan kuliner UKM. Pemerintah daerah melihat sektor kuliner paling disukai para wisatawan domestik dan mancanegara. Sektor inilah yang menjadi salah satu sumber pendapatan asli daerah (PAD) Kota Bandung.

\section{Kebijakan Ekonomi Kreatif Ber- basis Budaya Lokal}

Ekonomi kreatif berbasis budaya lokal membuka ruang bagi masyarakat Kota Bandung untuk berinovasi khususnya yang bergelut di bidang kreatif dan mendapatkan kemanfaatan 
ekonomi secara lang-sung dari aktivitas yang dilakukan atau digeluti. Negara, wilayah, atau daerah mampu menciptakan produk baru yang unik sehingga mampu memberikan nilai tambah secara ekonomis dan PAD.

Hasil penelitian, bahwa industri kreatif di Kota Bandung didominasi oleh kelompok busana (fashion), periklanan, kerajinan, dan desain. Sektor ini, bila dikelola maksimal, kontribusinya terhadap pendapatan produk domestik bruto (PDB) cukup signifikan. Inilah yang perlu diperhatikan dan diseriuskan oleh pemerintah daerah mengapa alasan industri kreatif di Bandung perlu terus dikembangkan. Ada 14 sub sektor industri kreatif, yakni peranti lunak (software), periklanan, riset dan pengembangan, seni pertunjukan, permainan interaktif, televisi dan radio, film, video dan fotografi, busana (fashion), desain, musik, kerajinan, arsitektur, pasar dan barang seni, penerbitan dan percetakan.

Hasil penelitian menunjukkan bahwa industri ekonomi kreatif tidak dapat lepas dari budaya lokal (local genius), yang telah memberikan ruh dan nilai-nilai bermakna dalam lingkungan kehidupan masyarakat. Artinya, ekonomi kreatif tidak hanya dipandang dari aspek ekonomi saja, tetapi juga dalam dimensi seni dan kebudayaan. Sebab ide-ide kreativitas telah lahir dari produk budaya yang sangat menentukan arah dan tujuan perkembangan ekonomi kreatif. Bila hal ini dikelola secara profesional, tak hanya PDB yang meningkat, tetapi dapat membuka lapangan kerja dan angka kemiskinan dapat teratasi secara bertahap. Kebijakan ekonomi kreatif berbasis budaya lokal ini dapat memberikan dampak terhadap ekonomi masyarakat lokal dengan mendayagunakan potensipotensi yang terdapat pada budaya lokal dan digunakan sebagai modal untuk meraih keuntungan secara ekonomis.

\section{Kebijakan Ekonomi Wisata Ber- kesinambungan}

Substantif kebijakan ekonomi wisata kota yang berkesinambungan tiada lain untuk mewujudkan sebuah kota yang berbasis wisata dan budaya dengan kearifan lokal (local wisdom). Kebijakan ekonomi wisata Kota Bandung mengintegrasikan kekuatan potensi lokal dengan sumber daya masyarakat lokal, hal ini tiada lain bertujuan guna membangun kekuatan baru di sektor pariwisata perkotaan antara kekuatan investor besar dan potensi yang dimiliki masyarakat Kota Bandung, sehingga mampu membangun kreativitas dan inovasi yang berkelas internasional. Harapan-Nya adalah membangun kota-mandiri bertarap internasional dengan destinasi wisata kota yang lebih modern dan terukur untuk kemajuan perekonomian masyarakat Kota Bandung.

Guna menyukseskan kebijakan destinasi wisata kota maka diperlukan berbagai potensi daerah termasuk sumber daya manusia yang memiliki kompetensi, profesional dan bertarap lokal, nasional maupun global. Kebijakan yang digulirkan tersebut, dari hasil penelitian lapangan telah membawa semangat baru bagi masyarakat yang tergabung dalam komunitas pembangunan kepariwisataan Kota Bandung. Penggerakan perekonomian pada sektor ini terus meningkat meski dibutuhkan kerja keras akibat masih fluktuasinya kunjungan wisman mancanegara ke Kota Bandung.

\section{Pemberdayaan Local Wisdom}

Perkembangan destinasi wisata kota di Kota Bandung, dalam beberapa tahun terakhir ini cenderung naik meski 
belum signifikan. Hal ini tentunya setelah dilakukan berbagai terobosan program wisata oleh pemerintah daerah, dalam hal ini Disbudpar Kota Bandung, telah menimbulkan berbagai dampak yang cukup luas bagi masyarakat lokal, baik dari sisi sosial, budaya, dan ekonomi. Dengan berbagai terobosan tersebut, diharapkan dapat meningkatkan kunjungan wisman mancanegara ke Kota Bandung.

Kesuksesan destinasi wisata kota di Kota Bandung, dibutuhkan perwujudannya secara bersama-sama, maka melalui peran serta masyarakat kota yang lebih merata, dan kesadaran masyarakat akan pentingnya destinasi, maka pemerintah daerah telah membuat berbagai program destinasi dengan kebijakan-kebijakan berkesinambungan yang selaras dengan visi dan misi Kota Bandung.

Kebijakan yang relatif popular dalam masyarakat adalah program pemberdayaan ekonomi pariwisata yang lebih dikenal, yakni;

a. Pengembangan destinasi wisata kota sebagai industri pariwisata yang berbudaya dan religius untuk meningkatkan perekonomian masyarakat dan PAD.

b. Pengembangan ekonomi kreatif masyarakat lokal melalui seni budaya lokal sebagai daya tarik Kota Bandung.

c. Pengembangan potensi UMKM masyarakat lokal, sebagai potensi ekonomi masyarakat Kota Ban-dung, dan potensi kuliner yang sangat digemari wisman mancanegara.

d. Pembangunan ekonomi wisata kota berkesinambungan, tiada lain untuk mengembangkan ekonomi rakyat berbasis potensi lokal, mengembangkan produk yang mampu bersaing di tataran global, sehingga masyarakat menjadi mandiri dari sisi financial. e. Peningkatan kesadaran wisata melalui peran dan fungsi berbagai komunitas dan kelompok masyarakat yang peduli wisata kota Bandung, merupakan elemen penting yang turut berkontribusi suksesnya destinasi wisata kota di Kota Bandung.

\section{Dampak Ekonomi Pengembangan Destinasi Wisata Kota}

Pengembangan destinasi wisata kota di Kota Bandung, sangat signifikan berkontribusi terhadap PAD Kota Bandung. Sektor ini, adalah satu sumber pajak daerah sehingga dibutuhkan penanganan serius agar sektor ini terus berkembang dan memajukan perekonomian masyarakat yang terkena dampak. Artinya, bagi pemerintah daerah dalam pengembangan destinasi tidak setengah hati dan perlu melibatkan masyarakat secara intens.

Hasil penelitian diketahui bahwa, adanya kebijakan destinasi wisata kota, masyarakat lokal yang terdampak telah memberikan pengaruh signifikan terhadap kehidupan masyarakat perkotaan yang lebih baik. Selain ekonomi meningkat juga memberikan peluang bagi tenaga kerja di sektor pariwisata Kota Bandung. Pada sisi investor, adanya kebijakan ini telah membuka akses kemudahan berinvestasi karena ada-Nya kemudahan membuka usaha baru pada liding sektor pariwisata. Berbagai inovasi dan stimulus pun telah dibuka oleh pemerintah daerah dengan tujuan untuk membangkitkan dunia pariwisata yang sempat menurun.

Bagi pemerintah daerah Kota Bandung, implementasi kebijakan destinasi wisata kota tiada lain untuk mewujudkan pelaksanaan program yang tertuang dalam visi misi sehingga pencapaian prestasi daerah. Selain itu, peningkatan pendapatan asli daerah dari 
sektor pariwisata terus ditingkatkan dan terbangunnya investasi dalam pembangunan Kota Bandung.

Melalui implementasi kebijakan yang kolaboratif diharapkan dapat membuka peluang usaha baru bagi masyarakat lokal dan terbukanya lapangan kerja bagi di sektor pariwisata dan sektor lainnya. Bagi masyarakat lokal, dengan penerapan kebijakan kolaboratif dapat membuka peluang ekonomi yang lebih besar sehingga percepatan kesejahteraan masyarakat segera terwujud. Inilah maknanya mengapa masyarakat harus terlibat di dalamnya, agar peran serta mereka dapat dirasakan langsung oleh masyarakat.

Dengan

berkembangnya

kepariwisataan Kota Bandung secara berkesinambungan, telah berdampak positif terhadap perekonomian masyarakat di sektor wisata. Selain itu, pemenuhan kebutuhan fasilitas umum sebagai pendukung pariwisata dan menjadi konsekuensi pemerintah daerah untuk melengkapinya, sehingga wisman domestik maupun mancanegara merasa nyaman dan betah tinggal lebih lama di kota Bandung.

Dampak yang ditimbulkan dari sarana dan prasarana ini, dapat dimanfaatkan oleh sebagian besar masyarakat pelaku pariwisata dalam mendukung pendapatan ekonomi masyarakat. Artinya, dengan penerapan kebijakan destinasi wisata kota oleh pemerintah yang berkelanjutan, maka semakin menguatkan peran lembaga dan organisasi masyarakat untuk samasama membangun kepariwisataan daerah dan semua kepentingan yang ada di dalamnya dapat terakomodir. Termasuk investor, maka dengan kebijakan tersebut, kemudahan berinvestasi semakin terbuka dan mudah serta adanya jaminan kepastian hukum dari pemerintah daerah Kota Bandung terhadap semua investor.

\section{KESIMPULAN}

Kota Bandung, secara ekonomi tergolong cukup baik dari seluruh kabupaten dan Kota, yang ada di Provinsi Jawa Barat. Sektor destinasi wisata Kota, telah melewati batas potensi ekonomi lokal, nasional dan telah mampu menembus pasar mancanegara. Ekonomi Kota Bandung, berbasis kerakyatan, lokal, seni dan budaya, pendidikan, dan religi telah berlangsung dengan baik. Kebijakan destinasi wisata kota telah selaras dengan tujuan ekonomi kerakyatan dan nasional.

Wujud dalam pemberdayaan masyarakat kota dalam aktivitas destinasi wisata kota telah mampu meningkatkan ekonomi masyarakat. Peran serta masyarakat lokal kini lebih terbuka namun tetap mempertahankan budaya lokalnya sehingga terjaga kelestarian dan keasliannya. Masyarakat lokal di sektor destinasi wisata kota tetap memerlukan pembinaan pemerintah daerah Kota Bandung, agar munculnya produkproduk baru masyarakat dalam perspektif kepariwisataan dapat terakomodir secara baik dan merata.

\section{UCAPAN TERIMA KASIH}

Ucapan terima kasih kepada semua pihak yang telah berperan kepada penulis terutama kepada teman-teman di Disbudpar Kota Bandung yang telah memberikan data awal dan informasi sebagai bahan penelitian, serta kepada seluruh civitas akademika STIA Bandung, yang telah berkontribusi dalam penelitian ini. Akhirnya, kami bersyukur Kepada Tuhan Yang Maha Esa yang telah memberi kami kekuatan dan kesehatan dalam menyelesaikan penelitian ini. Tidak lupa diucapkan 
terima kasih kepada pihak-pihak yang tidak dapat disebutkan namanya satu per satu, serta lembaga kami yang telah berkontribusi pemikiran dalam proses mempersiapkan penelitian ini. Penulis adalah dosen Sekolah Tinggi Ilmu Administrasi Bandung, juga merupakan Kepala Bapas Klas I Semarang.

\section{DAFTAR PUSTAKA}

\section{Jurnal:}

Ahmad, Lokman Mohd. Tahir, School Operational Funding to Support School Activities. (International Journal of Evaluation and Research in Education, Vol.3, No.1, March 2014, pp. 66-78.

Subhani Armin. 2012. Potensi Objek Wisata Pantai di Kabupaten Lommbok Timur. Tesis, program Studi Kependudukan dan Lingkungan Hidup, minat Utama: Pendidikan Georafi, Progaram Pascasarjana, Universitas Sebelas Maret Surakarta.

\section{Buku:}

Andrew Heywood, 2017. Political Theory: An Introduction, Second Edition, Palgrave New York, hlm 382.

Bachrach, Peter dan Aryeh Botwinick, eds. 1999. Power and Empowerment: A Radical Theory of Participatory Democracy. Philadephia: Temple University Press.

Bukart, A. J. dan Medlik, S. 1981. Tourism: Past, Present and
Future. Universitas Michigan: Heinemann, hal 40.

Dunn, William N. 2013. Analisis Kebijakan Publik. Yogyakarta: Gadjah Mada.

Edgell, Sr., et.al. 2010. Tourism Policy and Planning: Yesterday, Today, and Tomorrow Amsterdam: Elsevie.

Goeldner, Charles R. and J. R.Brent Ritchie. 2009. Tourism: Principles, Practices, PhilosophIes. 11th ed.

Grindle, Merilee S. 1980. Politics and Policy Implementation in The Third World. New Jersey: Princeton University Press.

Gronroos, Michael, 1998. Perceived Service Quality Model. Published Ohio University Press, California, hal 328.

Ismayanti. 2012. Pengantar Pariwisata.

PT. Gramedia Widiasarana Indonesia, Jakarta.

Pitana I. Gde dan Gayatri G. Putu. 2015. Sosiologi Pariwisata. Andi, Yogyakarta.

Pendit, Nyoman S. 2012. Ilmu Pariwisata, Sebuah Pengantar. Perdana. Jakarta. Pradnya Paramita hal 9-24.

\section{Situs:}

http://portal.bandung.go.id, diposting, 4 Juni 2020, pk. 14, 35.

https://money.kompas.com/read/2008/0 5/27/20160710/ Regional Jawa, diposting 5 Juni 2020.

Data BPS Kota Bandung, 2016. 